\title{
MARRIAGE, SPIRITUALITY AND MODERN SOCIETY:
}

\author{
Al-Ghazali's Thought
}

\author{
Uswah Azizah \\ Lembaga Sosial dan Agama Jepara \\ uswahsofa@gmail.com
}

\begin{abstract}
Marriage ideally should be a meaningful relationship, but in reality it is not the same. Modern society is questioning marriage that make them confronts dilemma which weaken social responsibility and family ties which, then, susceptible to domestic violence and even ended by divorce. This dilemma lead modern society seek for happiness outside marriage by choosing alternative of marriage; cohabitation, gay-parent family, or staying single (celibacy). The problem is modern society fail to find the meaningful relationship inside marriage. They fulfill material needs but fail fulfilling spiritual needs. This study is qualitative research which uses literature approach by focusing on the study of al-Gazali's thought about the virtue of marriage in tasawuf perspective. The data is analyzed using content analysis approach to reveal the content of al-Gazali's books. The virtue of marriage is the ethical significant of what lies behind the order of marriage. The virtue of marriage is that it is one of abstinence (riyadah an-nafs), it is done when fasting and restraining sight cannot curb sexual desire anymore. It is a necessary virtue for the conduct of spiritual exercises leading to union with God. Another virtue of marriage is that it is an act of devotion ('ibadah). It said so because there are many benefits (maslahah) inside marriage. Besides it can safeguard self from sinning if sight and adultery, it also beneficial in perpetuating mankind conform to the love of God. The virtue of marriage, in fact, can overcome the dilemma of modern society.
\end{abstract}

Keyword: Marriage, Modern Society, Ghazali's Thought.

\section{A. Introduction}

$\mathrm{M}$ arriage is a contract between husband and wife which is legally, socially, and religiously recognized. It provides male and female a chance to get biological relations. Marriage generally leads to the establishment of family life. Both male and female live together having their respective responsibilities according to their roles as assigned by society. ${ }^{1}$

Islamic doctrine is relevant anytime and anywhere. Islam does not make any difficulties for human in reaching happiness and beautiful life.

1 Saira Masood, Zahira Batool, \& Saif-Ur-Rehman Saif Abbasi, "Sociological Study of Marriage Patterns and Adjustment in a Selected Community in Faisalabad City (Pakistan)", Journal of Agriculture \& Social Sciences, (Pakistan: Department of Rural Sociology, University of Agriculture, 2007), 98. 
But there are several conditions should be fulfilled to make everything is allowed appropriate with Islamic and laws guidance. ${ }^{2}$

According to al-Gazali, human being have natural desire. There are two kinds of desire; appetite and sexual desire.4 Both desires are the greatest enemies of human faith (Iman) if it is not maintained properly. Marriage is such kind of remission to help them maintaining their desire so that their faith is safe. He mentioned that marriage is one of beautiful things in the world which can be very useful to help human preparing their hereafter life. ${ }^{3}$

However not everyone supports marriage. Some people may receive marriage because it is beneficial for them. But some others reject marriage for some reasons as well, particularly on modern age. Marriage has become obsolete by the changing of social expectations. Modern society rejects the idea of religious and government policy over marriage, or simply ignores such rules about licenses and ceremonies. ${ }^{4}$

On this modern age, everything is measured with material and logic. Physical and material prioritization produce consumerism culture and prioritization of mind and logic produce science and technology. But then, this kind of situation gives bad impact in other aspects of life, the spirituality decreases, and finally modern society lack of spirituality. ${ }^{5}$

Some ascetic people believe that marriage is such kind of barrier which makes them difficult to union with God, because everything around marriage is closer to worldliness and it what may cause them being far from God. Regarding this issue, al-Gazali's said that marriage is a starting point of spiritual exercise to get closer with Allah.

That is the reason of why the researcher is interested in examining how al-Gazali thinks about the virtue of marriage in tasawwuf perspective. Al-Gazali is a scholar which collaborating Islamic jurisprudence (fiqh) with Sufism. The researcher believes that al-Gazali can explain the relevance of marriage's virtue in modern lifestyle. So the concept of al-Gazali is compatible with modern civilization. Regarding the study, problems that may come around are what is the virtue of marriage according to al-Gazali? And what is the relevance of marriage's virtue in modern life?

\footnotetext{
${ }^{2}$ Muhammad Ali Ash-Shabuni, Hadiah Untuk Pengantin, trans. by Iklilah Muzayyanah, (Jakarta: Mustaqiim, 1995), 22.

${ }^{3}$ Al-Gazali, The Alchemy of Happiness, trans. by Claud Field, (Lahore: SH. Muhammad Ashraf, 1979), 56

${ }^{4}$ Anthony Giddens, Mitchell Duneier, \& Richard Appelbaum, Introduction to Sociology, sixth Edition, (New York: W. W. Norton \& Company, Inc, 2007), 477.

5 Bambang Sugiharto, "Posisi Ruh dalam Peradaban Modern", Spiritualitas dan Realitas Kebudayaan Kontemporer, (Yogyakarta: JALASUTRA, 2007), 5-6.
} 


\section{B. Marriage on al-Gazali's Perspective}

On his opening of Kitab Adab an-Nikah of Ihya' 'Ulum ad-Din, he mentioned that there were two points of view in Islamic religious circles. Those differences of opinions happen among scholars about the merits of marriage for religious life. One of the most important characteristics of early Sufism was the belief in asceticism as the prerequisite to a truly religious life. On one side there were those who stated that marriage was religiously better than exclusive (celibate) devotion to worship, and on the other side were those who stated the opposite, not to get married is better for increasing divine service. ${ }^{6} \mathrm{Al}-\mathrm{Gazali}$ explicitly placed his idea within a different opinion between supporters of marriage and advocates of celibacy.

Recommendation of marriage is actually motivated by the order to safeguard self from the badness of lust, which lust itself exists in all human being. According to al-Gazali, there are two kinds of desire; appetite desire (syahwah albatni) and sexual desire (syahwah al-farji). It is an entirely natural and primarily desirable part of the human constitution. ${ }^{7}$

According to al-Gazali, appetite desire is the fount of lust and the source of ailment and evil in that its cravings are followed by sexual desire. Food and sex lead to intense desire for ostentation and wealth, to all kinds of envy and greed (lit., rivalries and envies). Both give rise to the evil of deception, boastfulness, excessiveness, and ostentation (or, in modern terms, elitism). This in turn leads to hatred, envy, jealousy, enmity, and hostility, which (in turn) induces one to commit (what is) outrageous, objectionable, and adultery. ${ }^{8}$ Concerning to sexual desire, it has two faces. On a side it can give great benefit and pleasure, but it also will give a great danger and can destroy world and religion on another side, indeed, if it is not controlled, conquered, and released in the right place which appropriate with syari 'ah. ${ }^{9}$ Al-Ghazali suggested the novice to not married (celibacy) at the commencement of his undertaking, and until he acquires strength through ma'rifah, if during this period of time he is not disturbed by syahwah. In controlling sexual desire, alGhazali spelled three treatments to hush it; hungering/fasting (al-ju'), averting sight (gadd al-basar), and concentrating on that which preoccupies the heart (al-isytigal bisyuglin yastauli 'ala alqalb). if those treatment doesn't work to curb the lust, marriage is better choice to ease it so that one gets off from the catch of syahwah. ${ }^{10}$

\section{The Advantages and Disadvantages of Marriage According to al-Gazali}

Marriage plays such a large part in human affairs. It gives a big impact to the subject of marriage in many aspects of their life, whether it is good or bad. ${ }^{11}$ Al-Gazali spells out both of advantages and disadvantages of marriage to clarify which one is better.

\footnotetext{
${ }^{6}$ Al-Gazali, Ihya' 'Ulum ad-Din, Vol. 2, (Semarang: Karya Thoha Putra), 22.

${ }^{7}$ Al-Gazali, Ihya' 'Ulum ad-Din, Vol. 3, 77.

${ }^{8}$ Ibid., 77.

${ }^{9}$ Ibid., 96.

${ }^{10}$ Ibid., 98-100.

${ }^{11}$ Al-Gazali, The Alchemy of Happiness, trans. by Claud Field, (Lahore: SH. Muhammad Ashraf, 1979$), 101$.
} 
According him, there are five advantages of marriage; procreation, satisfying sexual desire, managing the household, providing companionship, and disciplining the self in striving to sustain them. ${ }^{12}$

1. Procreation

Procreation is the first and obvious advantage of marriage. Seeing that Allah create human genii for the purpose of worship, the aim of procreation is to sustain lineage and, therefore, the worshippers of Allah may increase in number. ${ }^{13}$

2. Satisfying Sexual Desire

The second advantage is fortification against the devil, curbing lust, warding off the excesses of desire, averting the eye, and safeguarding relief. Marriage is sufficient for bringing this about, a reason for causing it to be, and a safeguard against the evil of it becoming dominant. ${ }^{14}$

3. Ordering the Household

A further advantage of marriage is that there should be someone to take care of the house, cooking, sweeping, making beds, cleaning utensils, and means for obtaining support. It's difficult to live alone with all household duty. If a man is busy with his household duty, it can be confirmed that he has no time for learning, working, and praying. ${ }^{15}$ That is why the good woman is who takes care of the house and makes the virtues around the house, by means she helps her husband in religious aspect. ${ }^{16}$

4. Providing Companionship

The other advantage is comforting and relaxing the soul through companionship. Seeing and dallying with wife is comforting and relaxing the mind after being occupied in religious duties, and strengthening it for the performance of the obligatory rituals. A man may return to his devotions with renewed spirit after get that relaxation. ${ }^{17}$

5. Disciplining The Self in Striving to Sustain Them

The last advantage is disciplining the self and training it to be mindful, faithful, loyal, and respectful of the rights of the ahl (wives), tolerating their manners, enduring harm from them, striving to reform them, guiding them to the path of religion, striving toward making lawful gains for their sake, and undertaking the upbringing of their children. ${ }^{18}$

From all above, it can be seen that marriage is desirable. But on the other hand, there are dangers or disadvantages of marriage which lead some people prefer to choose unmarried better than married. Those are as follow:

${ }^{12}$ Al-Ghazali, Ihya' 'Ulum ad-Din, Vol. 2, 25.

${ }^{13}$ Al-Gazali, The Alchemy of Happiness, 101.

${ }^{14}$ Ibid., 27-28. See also, Al-Gazali, The Alchemy of Happiness, 101-102.

${ }^{15}$ Al-Gazali, The Alchemy of Happiness, 103.

${ }^{16}$ Al-Ghazali, Ihya' 'Ulum ad-Din, Vol. 2, 32.

${ }^{17}$ Al-Gazali, The Alchemy of Happiness, 102.

${ }^{18}$ Al-Ghazali, Ihya' 'Ulum ad-Din, Vol. 2, 32. 
1. The Inability to Seek Gain Lawfully

The first and the most serious difficulty which marriage can cause is the hardship involved in providing for family. It is not an eal thing for everyone to seek legal earnings, especially when he has instability of his life, it may drive man without independent means to seek illegal earnings. ${ }^{19}$

2. Failure to Uphold Wives Rights

The second difficulty is the failure to provide what is due to women and inability to forbear their bad temper.78 The husband is a leader in his family and has responsibility to carry on his family and save them from any bad things. ${ }^{20}$

3. Distractions from God

A third difficulty reflects the principal source of al-Gazali's reservations about marriage and satisfying sexual desire, that is, his preoccupation with the necessity of freeing one's soul from everything except good deeds which lead to ultimate happiness. This is incompatible with mundane things such as marriage and sexual intercourse. ${ }^{21}$

\section{The Virtue of Marriage According to al-Gazali}

Al-Gazali spelled that it is not enough for human only to know how to behave properly on social life, but it becomes essential for them to understand the reason behind it as well. Virtue is the ethical significant of what lies behind the actions, or it can be called as moral excellence as well. A virtue is a positive trait or quality deemed to be morally good and thus is valued as a foundation of principle and good moral being. ${ }^{22}$

Marriage was recommended for those whose sexual urges were too strong to contain. This lust (sexual desire) is the most overpowering of lusts confronting man and the most defiant when it excites the mind. Moreover, its aims are ugly. One is ashamed of its ends and fears its assaults. ${ }^{23}$

It should be known that desires (syahwah) are the starting point of all character training. On chapter before, it was explained that marriage is part of abstinence (riyadah annafs), as last way to overcome syahwah after three treatments ${ }^{24}$ are failed, even averting sight. Abstinence has a purpose to maintain the chastity of mankind. In abstinence, there are many virtues which cannot be estimated. That is to avert sinning. The one who marries will also free from sin of doing adultery. ${ }^{25}$

\footnotetext{
${ }^{19}$ Al-Ghazali, Ihya' 'Ulum ad-Din, Vol. 2, 34.

${ }^{20}$ Ibid.

${ }^{21}$ Mohamed Ahmed Sherif, Ghazali's Theory of Virtue, 63.

${ }^{22}$ Roberts Merrihew Adams, A Theory of Virtue: Excellence in Being on the Good, (New York: Oxford University Press, Inc., 2006), 8-9.

${ }^{23}$ Al-Ghazali, Ihya' 'Ulum ad-Din, Vol. 3, 101.

24 In controlling sexual desire, al-Ghazali spelled three treatments to hush it; hungering/ fasting (al-ju'), averting sight (gadd al-basar), and concentrating on that which preoccupies the heart (al-isytigal bisyuglin yastauli 'ala al-qalb).

${ }^{25}$ Al-Ghazali, Ihya' 'Ulum ad-Din, Vol. 3, 101
}

Teosofia: Indonesian Journal of Islamic Mysticism, Volume 5, Number 1, 2016 
There are several things should be noticed that there is correlation between physical and heart (qalb). Qalb is like a mirror, the essence of everything would not appear on it if it is not purified, lightened, and straightened. The method to purify it is by eliminating the badness of desire and bad attitude (akhlaq al-mazmumah). Lightening it is by the light of remembrance (zikr) and ma'rifah with the help of worship sincerely. And straightening it is by doing each physical movement on legal regulation. ${ }^{26}$

Another virtue of marriage is that it is an act of devotion ('ibadah). Al-Gazali said that marriage is one of devotion service outside compulsory worship, such as performing prayer, fasting, remembrance, etceteras. ${ }^{27}$

Children are the result of marriage and important factors in stabilizing the family foundations as well as a source of real joy to their parents. Of course it is the most desirable by every spouse. More than that, it is desired by Allah and His Messenger. Having children in order to perpetuate mankind conform to the love of God. ${ }^{28}$

Thus it has become clear that the virtue of marriage also lies in its being the means of having children. Virtue is also obtained from seeking intercession through the death of the young child should he precede his parent's death. ${ }^{29}$

Finally, suggestion and prohibition on syari'ah has purpose to lead mankind to the true happiness. The order of marriage has many advantages for human; Not only marriage bestows social prestige and status on man and woman, particularly on women, but it also incurs religious merit and virtues on its practitioners. Marriage as abstinence is a necessary virtue for the conduct of spiritual exercises leading to union with God, and also, related to the implementation of syari'ah, marriage is one of devotion service because it has many maslahah like mentioned.

\section{E. The Relevance of Marriage's Virtue in Modern Life}

Modern life today presents great challenges to Islamic teaching. Secularism and materialism become the biggest sponsors which contribute the difficulty for religious life. The biggest impact is human spirituality deceases a lot. An industrial work schedule, gender equality which makes woman is completely independence, and individualism; those are weakening social responsibility and family ties which, then, lead many marriage is end with divorce. ${ }^{30}$

One dilemma may be caused by media which reports the false image of marriage, even it also promoted by relatives and neighbors. Jourard, an experienced psychotherapist, has suggested that marriage today is literally a "disaster area": a state of marital rigor mortis where there is reciprocal victimization of both spouses. Yet, most newlyweds-to-be accept the fallacy that eternal bliss will be theirs to possess if they just marry the right

${ }^{26}$ Al-Gazali, 40 Prinsip Agama (Kitab al-Arba'in fi Usul ad-Din), trans. by Rojaya, (Bandung: Pustaka Hidayah, 2007), 86.

${ }^{27}$ Ibid.

${ }^{28}$ Al-Ghazali, Ihya' 'Ulum ad-Din, Vol. 2, 25.

${ }^{29}$ Ibid., 27-28.

${ }^{30}$ Michel Molloy, Experiencing the World's Religions: Tradition, Challenge, and Change, (California: Mayfield Publishing Company, 1998), 445. 
partner. Although the significance of mate selection must not be underestimated, it is often overshadowed by an atmosphere of mutual possessiveness -possibly the result of fears to accept change in spouse. Hence, marriage may be no more than an effort at mutual ego. ${ }^{31}$ Those who have physical, emotional or interpersonal problems are also in spiritual distress.

It has been mentioned that, according to al-Gazali, suggestion and prohibition on syari' ah has purpose to lead mankind to the true happiness. As part of syari' ah, the purpose of marriage is not only beneficial for human, it also has purpose to avoid damage.

Marriage is starting point of abstinence when someone cannot restrain his eye to overcome his lust (syahwah al-farj), after fasting and averting sight do not even work to curb it. For Sufi, sexual intercourse is one of the major media of distraction. Sinning by sight is one of the greater of the lesser category of sins leading one closer to the greater sin; namely adultery. Whereas satisfying sexual desire outside marriage is forbidden. ${ }^{32}$

It is contradictive with what has been done by modern society that they even questions the merit of marriage. According them, marriage cannot assure them to get happiness and pleasure as they want anymore. They think that they also can get the same happiness and pleasure as marriage without getting married. ${ }^{33}$

Hence, those dilemmas drives many modern people reject marriage and choose to stay single (celibacy), or even other alternative matrimonies outside traditional marriage form, such as cohabitation 29 or even gayparent families which really forbidden by syari' ah. ${ }^{34}$

Modern society emphasizes their paradigm on material-profane cases. As bidimensional creature, they should not forget that there is spiritual dimension within everything. ${ }^{35}$ Spirituality are powerful dimensions of human experience involving transcendent beliefs and practices that foster meaning, well being and connectedness often within an organized system.

Talking about the virtue of marriage, it leads people to live virtuous and full of happiness. According to al-Gazali, one who wants to marry, he should have the right intention and commitment in marriage to reach physical and spiritual pleasure. Marriage is such abstinence which becomes a starting point to conduct spiritual exercises leading to reach higher inner balance and peace, and to union with God. The spouse should remind that his intention is to worship Allah and running his household with true commitment to perpetuating his marriage by behaving well and fulfilling each all rights and duties.

${ }^{31}$ Sidney M. Jourard, "Marriage is For Life", The Changing Family: Making Way for Tomorrow, (San Francisco: Holt, Rineheart and Winston, n. d.), 177. It is reprinted from, Sidney M. Jourard, "Marriage is For Life", Journal of Marriage and Family Counseling, July 1975,199-208.

${ }^{32}$ Al-Ghazali, Ihya' 'Ulum ad-Din, Vol. 3, 98.

${ }^{33}$ Nurcholish Madjid, Malarakat Religius; Membumikan Nilai-Nilai Islam dalam Kehidupan Malarakat, (Jakarta: Paramadina, 2004), 71.

${ }^{34}$ Anthony Giddens, Mitchell Duneier, \&Richard Appelbaum, Introduction to Sociology, 6th Ed., (New York: W. W. Norton \& Company, Inc, 2007), 496-500.

${ }^{35}$ Don Swenson, Society, Spirituality, and the Sacred: a social scientific introduction, (Canada: Broadview Press, 1999), 305. 
Modern life causes woman has the same position with man even higher. This equality brings them become more independent in social and economical. So that woman may be the leader of the family because she may be more independent than her husband. Such thing may lead to marriage instability. This condition is compounded by individualism which makes it in more serious condition. The result is there are a lot of marriages are far from meaningful marriage, which susceptible to domestic violence, and even ended by divorce.

Islamic teaching clearly places man above woman. It is related to family life that man is family leader which should be obeyed by all family member, moreover wife. It is supported by al-Gazali that wife should obey her husband absolutely in everything he demands as long as it suitable with an act of obedience to God. ${ }^{36}$

It has been mentioned before that Islam has a great attention for human psychological prosperity by prescribing several ethics that should be obeyed by everyone, moreover in ethical relationship in marriage. It has mentioned that physical, emotional or interpersonal problems are also in spiritual distress. The purpose of ethical behavior in marriage is helping the spouse fostering their spirituality to overcome their crisis. Spirituality influences ways of coping with adversity, the experience of suffering, and the meaning of symptoms. ${ }^{37}$

Essentially, Human are spiritual being, so all families are, basically, also spiritual. Spirituality is a vital resource that helps families manage crises and maintain equilibrium. Those dilemma mentioned, which lead to alternative matrimonial choice outside traditional marriage form, which even forbid by Islam, would not happen if both spouses realize that beside they should fulfill their material needs, they should concern to their spiritual needs as well. $^{38}$

The purpose of marriage is not for getting pleasure from sexual intercourse or other physical happiness, but it is actually a starting point of abstinence which leads to conduct spiritual exercise in order to worship and union with Allah. The virtue of marriage become such power and aid for spouse, by this way, to makes their marriage stay balance, so that they can achieve the peaceful and meaningful marriage.

\section{F. Conclusion}

The virtue of marriage is the ethical significant of what lies behind the order of marriage. According to al-Gazali, suggestion and prohibition on syari'ah have purpose to lead mankind toward the true happiness. Since marriage is a part of Syari'ah, it has purpose to bring goodness (maslahah) which beneficial for man, and preventing badness (madarah) as well.

\footnotetext{
${ }^{36}$ Al-Gazali, Menyingkap Hati Menghampiri Ilahi (Mukalafah al-Qulub), trans. by Irwan Kurniawan, (Bandung: Pustaka Hidayah, 2012), 195.

${ }^{37}$ George Nedumaruthumchalil, "The Role of Religion and Spirituality in Marriage and Family Therapy", Journal of Pastoral Counseling, vol. 44, (New York: Iona College, 2009), 14.

${ }^{38}$ Ruth A. Tanyi, Spirituality and Family Nursing: Spiritual Assessment and Interventions for Families, (New York: McGraw-Hill, 2008), 108.
} 
The virtue of marriage is that it is one of abstinence (riyadah annafs), it is done when fasting and restraining sight cannot curb sexual desire anymore. This is also an indication that its virtue is in safeguarding against disobedience, and fortifying against corruption. According him, sexual desire is major media of distraction on getting closer toward God if it is not curbed well. Distraction here is being far from Allah and closer to the greater sin, that is adultery. So it should be curbed by marriage, because abstinence is a necessary virtue for the conduct of spiritual exercises leading to union with God.

Another virtue of marriage is that it is an act of devotion ('ibadah). Al-Gazali said that marriage is one of devotion service outside compulsory worship, such as performing prayer, fasting, remembrance, etceteras. It is related to the implementation of syari'ah, marriage is one of devotion service because it has many benefits (maslahah), it is safeguarding self from sinning if sight and adultery, it also beneficial in perpetuating mankind conform to the love of God. Besides, al-Gazali also mentioned that the prayers of children profit their parents when the latter are dead, and children who die before their parents intercede for them on the Day of Judgment.

The relevance of marriage's virtue with modern life is it can overcome the dilemma of modern society. The paradigm of modern society leads them to understanding that spirituality is not important thing and it is not include in marriage's virtues. Individualism gives sickness on marriage, much domestic violence happen inside and even ended by divorce. A lot number of marriages are far from meaningful marriage. That is why they think that marriage no more give happiness This dilemma lead modern society seek for happiness outside marriage by choosing alternative of marriage; staying single (celibacy), even doing cohabitation, or being gay-parent family which clearly forbidden by Islamic teaching. The order of marriage on syari'ah precisely has purpose to lead mankind to the true happiness. Leaving marriage and choose another matrimonial alternative is not recommended way to curb sexual desire. Because it is a media of distraction, it should be curbed by marriage. According to al-Gazali, one who wants to marry, he should have the right intention and commitment in marriage to reach physical and spiritual pleasure. Marriage is such abstinence which becomes a starting point to conduct spiritual exercises leading to reach higher inner balance and peace, and to union with God. The spouse should remind that his intention is to worship Allah and running his household with true commitment to perpetuating his marriage by behaving well and fulfilling each all rights and duties. It helps the spouse to overcome their crisis (being aid for their mental in coping marriage problem that may arise) and making marriage stay balance, so that they can achieve the meaningful marriage. 


\section{Bibliography}

Al-Gazali, Abu Hamid, Ihya 'Ulum ad-Din. Semarang: Karya Thoha Putra, 1979.

, The Alchemy of Happiness, trans. by Claud Field, Lahore: SH. Muhammad Ashraf, n.d.

, Kitab Adab an-Nikah, trans. by Imam Abu Asma Anshari, Etika

Perkawinan (Membentuk Keluarga Bahagia), Jakarta: Pustaka Panjimas, 1993. , Majmu'ah Rasail al-Imam al-Gazali, trans. by Irwan Kurniawan,

Risalah-Risalah al-Ghazali, Bandung: Pustaka Hidayah., 1997. , al-Munqiz min ad-Dalal, trans. by Nasib Musthafa. Penyelamat

Jalan Sesat, Jakarta: CV. Cendekia Sentra Muslim, 2002.

, Kitab al-Arba'in fi Usul ad-Din, trans. by Rojaya, 40 Prinsip

Agama, Bandung: Pustaka Hidayah, 2007. , Mukalafah al-Qulub, trans. by Irwan Kurniawan, Menyingkap

Hati Menghampiri Ilahi, Bandung: Pustaka Hidayah, 2012.

Az-Zuhaili, Wahbah, al-Fiqh al-Islam Wa Adillatuhu, Damsyiq: Dar al-Fikr, 1989.

Giddens, Anthony, Mitchell Duneier and Richard Appelbaum, Introduction to Sociology.

New York: W. W. Norton \& Company,Inc., 2007.

Gilbert, Kathleen R., Ruth Tanyi, et al., The Family. New York: McGraw-Hill, 2008.

Sabiq, Sayyid, Fiqh al-Sunnah, trans. by Mahyudin Syaf, Fikih Sunnah, Bandung: PT Alma'arif, 1982.

, Fiqh al-Sunnah, trans. by Nor Hasanuddin. Fiqih Sunnah, Jakarta: PT. Pena Pundi Aksara, 2007.

Saira M., Zahira B., and Saif-Ur-Rehman S. A., et al., Journal of Agriculture and Social Sciences. Pakistan: Department of Rural Sociology, University of Agriculture, 2007.

Savells, Jerald., Lawrence J. Cross, and Sidney M.Jourard, et al., The Changing Family: Making Way for Tomorrow, San Francisco: Holt, Rineheart and Winston, 1978.

Ash-Shabuni, Muhammad Ali, Hadiah Untuk Pengantin, Jakarta: Mustaqiim, 1995.

Sherif, Mohamed Ahmed, Ghazali's Theory of Virtue, Albany: State University of New York Press, 1975.

Smith, Margaret, Al-Ghazali The Mystic, Lahore: Hijra International Publishers, 1983.

Stanczak, Gregory C. and Donald E. Miller, Engaged Spirituality: Spirituality and Social Transformation in Mainstream American Religious Traditions, California: Center for Religion and Civic Culture University of Southern California, 2004.

Sulaiman, Fathiah Hasan, Al-Ghazali dan Plato dalam Aspek Pendidikan, Surabaya: Bina Ilmu, 1986.

Swenson, Don, Society, Spirituality, and The Sacred: A Social Scientific Introduction. Canada: Broadview Press, 1999.

Watt, William Montgomery, Muslim intellectual: a Study of al-Ghazali, Chicago: Aldine Publishing Company, 1971. 